\title{
Application of Constructed Wetland in Sewage Treatment in Counties and the Desert Greening
}

\author{
Shiqin $\mathrm{Hu}^{1}$, Bin $\mathrm{Fan}^{2}$, Wei Ou${ }^{3}$ \\ ${ }^{1}$ Xinjiang Vocationl and Technical College of Construction \\ ${ }^{2}$ Xinjiang Urban and Rural Planning Design Instiute \\ ${ }^{3}$ Xinjiang Pishan County Supplying and drainage company
}

KEYWORD: Constructed wetland; Sewage treatment; Desert greening

ABSTRACT: this paper, Pishan county sewage treatment and the desert greening have been studied.We have analyzed the advantages and disadvantages of the wetland mechanism and its purification in the sewage treatment in Pishan county as the test results of reused sewage for greening the desert.It has proved that the constructed wetland sewage can be made to receive significant environmental, economic and social benefits. Deeply studying has demonstrated that constructed wetland mechanism in arid areas will change the environment of Xinjiang and that of the country.

\section{INTRODUCTION}

At present, most towns in northwest area are under dual pressures from water shortage and water environment pollution, and regeneration of the sewage using can make up for the lack of seasonal rivers and urban landscape water, reduce the amount of sewage, improve the quality of the environment; economize on the use of fresh water resources, solve the problems of the requirements of water for the urban ecological environment, water and other low quality water (industrial, municipal departments water) demand. Especially in the near future, from the point of view of the national strategy for the layout and capital investment, we cannot implement immediately the Water Diversion Project through the western route from the south to the north. In this case, the urban sewage and industrial sewage recycling will be the fundamental guarantee that could promote economic development in the northwest area and the water resources supply. Rational use of the ecological treatment process which is fit for the level of local operation and management, such as the stable pond and constructed wetlands, improve the sewage treatment effect and reduce the cost of sewage treatment is the premise of improving combination of the sewage treatment and use.

\section{MECHANISM OF CONSTRUCTED WETLAND POLLUTION REMOVAL}

Constructed wetland (wetlands constructed) is an ecological system for sewage treatment with the feature of wetlands which is constructed by human beings. It is based on the theories of land treatment system and the principle of the sewage treatment by using aquatic plants. Simply speaking, it is the wetland that is constructed by people according to their needs on the certain locations by imitating the structure and function of the natural wetland.

\section{The composition of constructed wetlands}

Constructed wetlands are mainly composed of five parts: water, substrate, aquatic plants, aquatic animals and their microbial communities.

\section{Types of constructed wetlands}

According to the different ways of sewage flow in the wetland bed, it can be divided into two categories: the surface flow wetland and subsurface flow constructed wetland. Subsurface flow constructed wetland can be categorized as horizontal flow constructed wetland and vertical flow constructed wetland.

Surface Flow Wetland, SFW is also known as the Free Water Surface. It has the advantages of little investment, simple operation as well as the disadvantages of small load, large covers and is greatly 
affected by the climate. In the northern region, the surface is icy in winter, and mosquito breeding and foul smell everywhere in summer and so on.

\section{Mechanism of constructed wetland pollution removal}

1. Mechanism of nitrogen removal and transformation

The nitrogen in the sewage of the constructed wetland is generally in the presence of organic nitrogen and inorganic nitrogen ( $\mathrm{NH} 4$ 十一N, N03 "-N). Ammonia and nitrogen in the sewage can be used as an essential material for plant growth that could be absorbed directly by plants, and synthesizes the plant protein and organic nitrogen, and thus can be removed from the wetland system by plant harvesting. Fig. 1is the nitrogen processing model schematic diagram[1].

2.Mechanism of phosphorus removal and transformation Phosphorus is often in its presence of phosphate $\left(\mathrm{P}^{3} 4^{\mathbf{3}}, \mathrm{HPO} 4^{\mathbf{3}}, \mathrm{H}_{\mathbf{2}} \mathrm{PO} 4^{-}\right)$, poly phosphate and organic phosphorus in sewage. Constructed wetland can use the coordinate physical, chemical and biological function of the complex ecosystem which contains the soil, microbes and plants to remove the phosphorus in sewage effectively by filtration, adsorption, co-precipitation, ion exchange, plant absorption and microbial decomposition. in this, through to achieve on the removal efficiency of. The removal of phosphorus in constructed wetland system is mainly through 3 aspects: the absorption of plants, the removal of microorganisms and the physical and chemical effects of substrates.

\section{DISCUSSION ON THE CONSTRUCTED WETLAND SEWAGE TREATMENT IN PISHAN COUNTY}

The purpose of the comparative analysis is: whether the advantage of constructed wetland sewage treatment is still with its strength in Pishan county because the disadvantages of the wetland is in the role of limiting in Pishan county, say whether the function of limiting is strengthened or weakened. If it is weakened, it is more proper to be used.

The advantages of constructed wetland sewage treatment in Pishan county
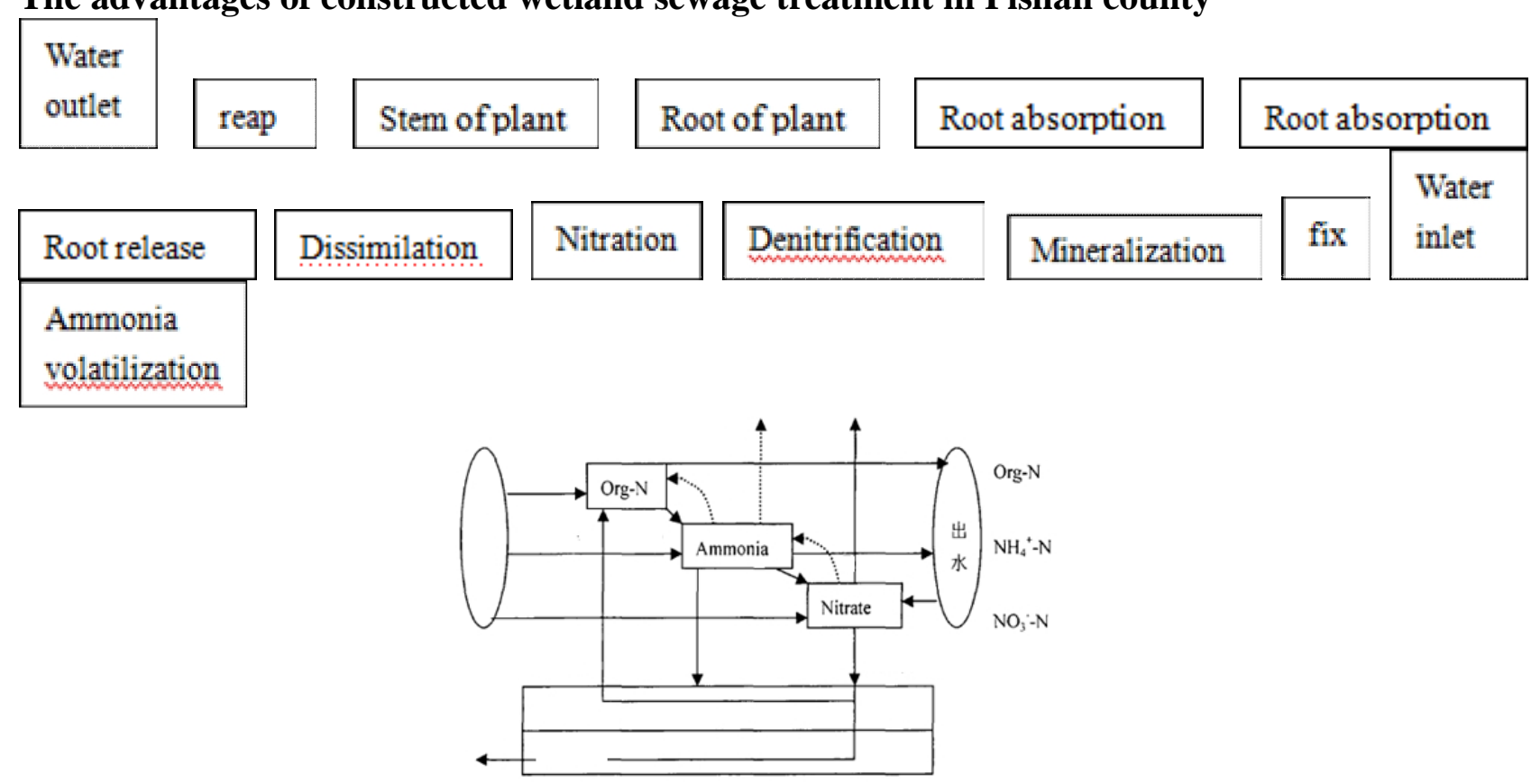

Fig.1Nitrogen Processing model schematic diagram

1. The high efficiency of treating sewage, especially the high removal rate of $\mathrm{N}$ and $\mathrm{P}$ can prevent the eutrophication of the local water. The constructed wetland takes high rate in the removal of COD, BOD5, SS, N, P and the amount of bacteria, and these are the main pollution Indicators in the sewage of Pishan county; especially, the high removal rate of $\mathrm{N}$ and $\mathrm{P}$ can prevent the eutrophication 
of the local water, so this is one of the greatest advantages of the application of constructed wetland in Pishan county.

2. Low investment, low operation cost, and low maintenance technology guarantee the construction and effective operation of the sewage treatment facilities in Pishan county .

Constructed wetland system removes the secondary sedimentation tank in the mechanical treatment, uses the plant oxygen to replace the aeration machine, so that it consumes low energy and saves the investment; comparing with the stable ponds, constructed wetland replaces the aerobic pond with less pollution load, thus, saves the land area. By comparing the sewage treatment schemes of middle and small counties in Xinjiang, there are three schemes of investment, operation cost and area covers of the project for treating per cubic meter of sewage which are shown in the following table 1 .

3. Flexible design of constructed wetland sewage treatment system is very suitable for less discharge and the city whose sewage disposal is in its stage development.

4. Unique ecological aesthetic features increases the beauty of the environment

Compared with the traditional treatment facilities, constructed wetland contains a large number of aquatic plants which forms a beautiful green landscape. Many plant in constructed wetland enjoys a high ornamental value. The wetland water which has aquatic plants provides a suitable living environment for fish, waterfowl and other wildlife, improves the biological diversity, thus, it enjoys the function of ecological aesthetics as is shown in Figure 1.

Table1. Comparison of the Main Indicators of Three Schemes of Sewage Treatment Plants

\begin{tabular}{|c|c|c|c|}
\hline Schemes & $\begin{array}{c}\text { Secondary Mechan- } \\
\text { ical Treatment }\end{array}$ & $\begin{array}{c}\text { Stable } \\
\text { Pond }\end{array}$ & $\begin{array}{c}\text { Construc-ted } \\
\text { Wetland }\end{array}$ \\
\hline $\begin{array}{c}\text { Project Investment } \\
\text { (Thousands RMB) }\end{array}$ & 1865 & 487 & 480.2 \\
\hline Project Covers (Hectare) & 1.71 & 5.68 & 4.48 \\
\hline $\begin{array}{c}\text { Operation Cost/Year } \\
\text { (Thousands RMB) }\end{array}$ & 126 & 42.9 & 36.2 \\
\hline
\end{tabular}

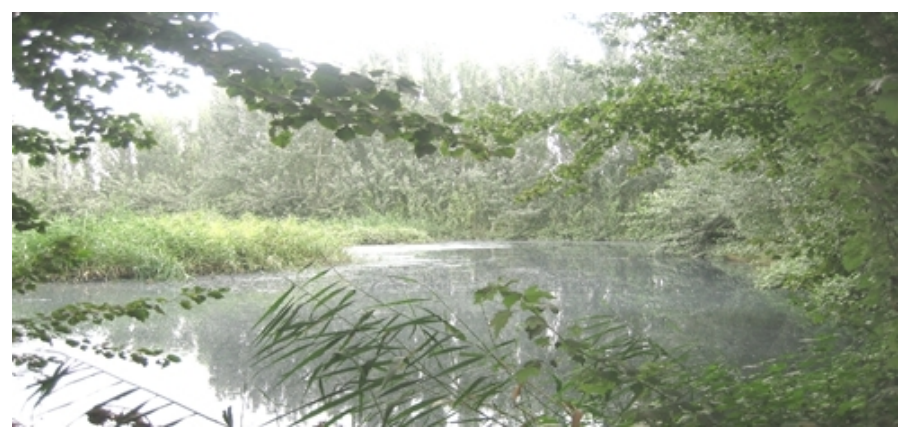

Figure 2. Constructed Wetland Sewage Treatment System in Pishan County 


\section{The disadvantages of constructed wetland sewage treatment in Pishan county}

\section{Relative large covers}

The total area of Pishan county is 41167 square kilometers: the mountains account for $37.9 \%$, plains account for $22.6 \%$, deserts account for $39.5 \%$. The county was divided into56 oasis by the Gobi and deserts, among which, the area of oasis is 167693.6 hectares, accounting for $4.2 \%$ of the total area. Therefore, larger covers would not be a problem to build a constructed wetland sewage treatment system in Pishan County which has widely distributed desert.

\section{Limited by climate conditions}

Pishan county belongs to continental climate, the annual average temperature there is 11.8 degrees centigrade, the average temperature in the hottest July is 25.4 degrees centigrade, and the average temperature in the coldest January is -6 degrees centigrade. Throughout the year in January, the surface of the water becomes icy, and the organics in the sewage which is stored in the wetland can be slowly decomposed by the microorganisms in the matrix. It produces a certain effect to the sewage purification. However, due to the limited glacial period and wetland has the function to store, precipitate and slowly decompose the sewage, the low temperature in winter has little impact on the treating effects of constructed wetland sewage treatment system in Pishan county.

3. Easy to produce deposition

The dredging of constructed wetland of Pishan County is arranged in winter because there are stretches of desert outside the Pishan County and it is easy to build spare pools with less investments. At the time of dredging, the sewage is introduced into the reserve pool and when it is finished, the sewage is introduced into the constructed wetland treatment system to be purified.

4. Plants are easy to suffer the threats from the plant diseases and insect pests and the harmful substances in the sewage

Recently, the capacity of sewage treatment in Pishan county is $5000 \mathrm{~m} 3$ / D, and will be $8000 \mathrm{~m} 3$ / D in the future. The constructed wetland sewage treatment system is not in a big size and it is unlikely to occur large area of plant diseases and insect pests and reed plant diseases and insect pests and pest control are not difficult to cure and easy to manage. The sewage in Pishan county is sewage in life. The quality index of inlet water in the sewage treatment plants are shown in table 3-3. Therefore, the emissions of pollutants in Pishan County are mainly non-toxic organics and $\mathrm{N}$ and $\mathrm{P}$ nutrients. There are little toxic substances so that it won't be a threat.

Table2.The Water Quality Index of Pishan County Sewage Plant

\begin{tabular}{|c|c|c|c|c|c|}
\hline $\begin{array}{c}\text { BOD5 } \\
\mathrm{mg} / \mathrm{l}\end{array}$ & $\begin{array}{c}\mathrm{SS} \\
\mathrm{mg} / \mathrm{l}\end{array}$ & $\begin{array}{c}\mathrm{COD} \\
\mathrm{mg} / \mathrm{l}\end{array}$ & $\begin{array}{c}\text { Ammonia } \\
\text { Nitrogen } \\
\mathrm{mg} / \mathrm{l}\end{array}$ & $\begin{array}{c}\text { Total- } \\
\text { Phos- } \\
\text { phorus } \\
\mathrm{mg} / \mathrm{l}\end{array}$ & $\mathrm{PH}$ \\
\hline 200 & 250 & 350 & 35 & 5 & $7 \sim 9$ \\
\hline
\end{tabular}

\section{SEWAGE REUSE GREENS THE DESERT}

The standard of windbreak irrigation per acre, say, 800 cubic meters / acre year, can green 2000 acres of deserts which needs 224000 saplings in total for afforestation. Since 1998, Pishan County introduced the treated sewage to plant native tree species, such as Xinjiang poplar, Tamarix and Calligonum mongolicum to test, the survival rate of these trees is up to $75 \%$ and they are resisted to alkali and sand bury, growing well currently. (as is shown in Figure 2, 3). Through several years of introducing experiments and investigation, during the process of desert biological protective system construction in Pishan county, the selection of plant species should be from the mix planting of the shrub species and Xinjiang hybrid poplar, such as Tamarix and Calligonum mongolicum which are superior to the sand fixing, to form the combination of arbor and shrub, stereo windbreak and sand 
fixation structure system, for some areas, other economic shrubs, such as the Chinese wolfberry and seabuckthorn could be the options.

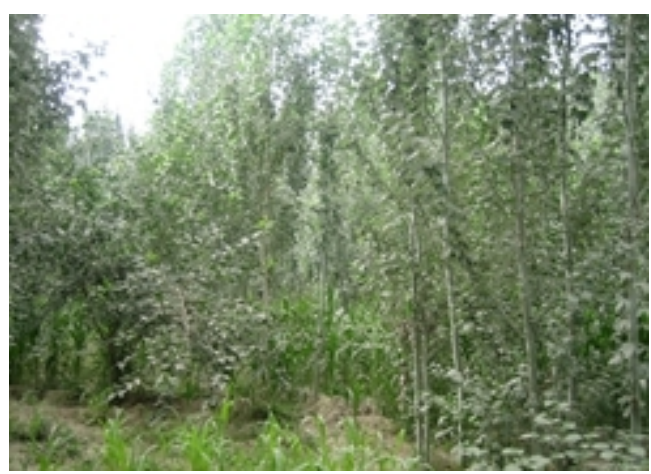

Figure 3 Xinjiang Poplar Planted after the Sewage Treatment in Pishan County

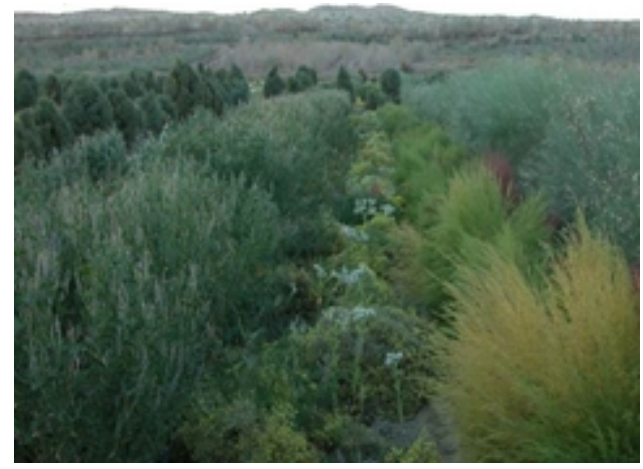

Figure 4 Tamarix and Calligonum Mongolicum in the Smooth Sand-lands in Pishan County

\section{PREFERENCES, SYMBOLS AND UNITS:THE ENVIRONMENTAL BENEFITS, ECONOMIC BENEFITS AND SOCIAL BENEFITS OF SEWAGE TREATMENT AND REUSE}

\section{Environmental benefits}

Currently, the sewage trunk in Pishan county is 5.7 kilometers in length, and the treatment rate reached more than $75 \%$, irrigated 120 acre of shelter forests, and not only initially formed a beautiful green landscape, but also played a role of windbreak and sand fixation. the air quality of the country has been significantly improved, and the quality of surface water and groundwater has been improved by years. Moreover, the secondary sewage treatment project is in the process of application, the current daily sewage treatment capacity reached 5000 cubic meters, and the long-term sewage daily processing capacity is of 8000 cubic meters. All the treated sewage can be up to the standards of the irrigation water quality, which played a role of storage in winter and irrigation in summer., transformation of the saline and restored the vegetation, afforestation, environmental protection and brought other comprehensive benefits.

\section{Economic benefits}

According to the recent statistics of the water treatment capacity of 5000 tons in the secondary project of Pishan county sewage treatment, it could green 2000 acres deserts. Using the stereo structure with the combination of arbor and shrub to plant Xinjiang poplar, Tamarix and Calligonum plants to estimate the economic benefits, the annual sewage treatment costs 1.55 million yuan, and the greening tree species invests 33.4 thousand yuan, then the annual sewage treatment and desert 
greening investment cost 160 million; annual fee for drain the contamination for sewage earns 1.46 million yuan, the annual savings from greening water is 2.1 million yuan, the indirect fee from the water which greens the desert is 1.01 million yuan per year (according to the statistics, per acre forest could save 20 tons more water than the area without any forests); so the economic benefit in a year for desert greening is about 2.97 million yuan.

\section{Social benefits}

The sewage treatment and reuses technology brings Pishan county not only a corresponding environmental benefits and certain economic benefits, but also shows a model for the combination of sewage treatment and utilization in the drought desert area with little rain in Xinjiang. Certainly, the technology which is involved in the project can also be applied and spread in the drought desert and Gobi Town of Hami, Shanshan, Turpan, Korla, Aksu, Kashi, Karamay, Shihezi, etc. in Xinjiang to open up a new way of broadening the resources and reducing the expenditures, comprehensive utilization of sewage and urban greening in these drought area in order to promote the sustainable development of the ecological environment in these arid areas, and promote the development of local economical construction.

\section{CONCLUSION}

China is a country with water shortage, especially in the northwest region where is drought and less rain. The problem of greening the Gobi desert is to solve the problem of water. Using constructed wetland sewage treatment system is easy to operate and manage with less investment and it is more suitable for sewage treatment in small towns to treat domestic sewage and it is suitable for its economic and technological development. Therefore, the in-depth study of constructed wetland treatment system and vigorously promote the combination of sewage treatment and desert greening technology will change the ecological environment in the arid regions of Xinjiang and even the whole country.

\section{ACKNOWLEDGEMENTS}

Construction research and development project, Project No.: 06-K4-24, Title of the project: A Study on the Technology of Sewage Reuse in the Desert of Xinjiang

\section{REFERENCE}

[1]TannerCC,KadlecRH,GibbsMM,etalNitrogenProcessinggradientsinsubsurfaee - flow treatmentWetlands.EcologyEngineering.2002,18:499-520. 